\title{
The protective effect of niacinamide on CHO AA8 cell line against ultraviolet radiation in the context of main cytoskeletal proteins
}

\author{
Magdalena Izdebska, ${ }^{1, A, C, D, F}$, Marta Hałas-Wiśniewska, ${ }^{1, A, C, D, F}$, Iwona Adamczyk ${ }^{2, A, B, F}$, \\ Ismena Lewandowska ${ }^{2, A, B, F}$, Iga Kwiatkowska ${ }^{2, A, B, F}$, Maciej Gagat ${ }^{1, C, E, F}$, Alina Grzanka ${ }^{1, C, E, F}$ \\ ${ }^{1}$ Department of Histology and Embryology, Faculty of Medicine, Collegium Medicum in Bydgoszcz, Nicolaus Copernicus University in Toruń, Poland \\ ${ }^{2}$ Students' Research Group of Cell Biology and Ultrastructure, Department of Histology and Embryology, Faculty of Medicine, Collegium Medicum in Bydgoszcz, \\ Nicolaus Copernicus University in Toruń, Poland \\ A - research concept and design; B - collection and/or assembly of data; $\mathrm{C}$ - data analysis and interpretation; \\ $D$ - writing the article; $E$ - critical revision of the article; $F$ - final approval of the article
}

Address for correspondence

Magdalena Izdebska

E-mail:mizdebska@cm.umk.pl

\section{Funding sources}

This study was supported by a research task within the framework of the statutory activities and students' research (Collegium Medicum in Bydgoszcz, Nicolaus Copernicus University in Toruń, Poland).

Conflict of interest None declared

Received on 0ctober 7, 2016 Reviewed on 0ctober 18, 2016 Accepted on January 5, 2017
DOI

$10.17219 /$ acem/68289

\section{Copyright}

Copyright by Author(s)

This is an article distributed under the terms of the Creative Commons Attribution Non-Commercial License (http://creativecommons.org/licenses/by-nc-nd/4.0/)

\begin{abstract}
Background. Niacinamide is a stable and water-soluble form of vitamin $B_{3}$, a valuable and versatile cosmetic ingredient, which is well absorbed and tolerated by the skin. A large body of literature has reported on the antioxidant and cell repair properties of niacinamide. Therefore, it has been shown to be useful in the protection of the skin against ultraviolet $B$ (UVB) radiation and free radicals. Despite numerous hypotheses on the mechanism of vitamin $B_{3}$, its protective effects have not yet been fully elucidated.

Objectives. The aim of the study was to determine the protective effects of niacinamide on CHO AA8 cell line against UVB radiation. We assessed the following factors: cell death, cell cycle phase distributions, reorganization of main cytoskeletal proteins, such as F-actin, vimentin and $\beta$-tubulin, and also alterations at the ultrastructural level.
\end{abstract}

Material and methods. The material used for our research was Chinese hamster ovary cell line (CHO AA8). We used 4 research groups: 1) control cells; 2) cells treated with niacinamide; 3) cells exposed to UV radiation; and 4) cells co-incubated with niacinamide and next exposed to ultraviolet. The cell death and cell cycle were evaluated by a Tali ${ }^{\circledR}$ based-image cytometer. A fluorescence microscope was used to assess the reorganization of cytoskeletal proteins, whereas a transmission electron microscope enabled the evaluation of the alterations at the ultrastructural level of cells.

Results. We showed that UV-induced apoptosis and cell cycle distributions during treatment with niacinamide resulted in a non-statistical significance in cell survival and no significant changes in the morphology and cytoskeleton in comparison to the control group. In turn, a combination of both factors led to an increase in the population of live cells and a decreased level of apoptotic cells in comparison to UV-exposed cells.

Conclusions. Our results confirmed the harmful effects of UV radiation on CHO AA8 cell line. Furthermore, niacinamide can protect cells against these factors, and the mechanism of action may be related to the stabilization of the cell cytoskeleton.

Key words: UV radiation, F-actin, vimentin, niacinamide, $\beta$-tubulin 


\section{Introduction}

Vitamin $\mathrm{B}_{3}$, also known as niacin (nicotinic acid vitamin), is found in several forms, including niacinamide (nicotinamide; Niac). Furthermore, as niacin cannot be synthesized by the human body, it has to be delivered to the organism from the environment. It can be found in many foods, such as green vegetables, beans, milk, eggs, yeast, and meat or fish. Vitamin $B_{3}$ is involved in the mechanisms of DNA repair and genomic stability. Furthermore, niacin deficiency results in an increased rate of somatic mutations and toxicity caused by reactive oxygen species (ROS), which is associated with an increased risk of cancer and its elevated progression rate. ${ }^{1,2}$ Niacinamide is an amide form of vitamin $B_{3}$, and it is also known as the precursor of important cofactors: niacinamide adenosine dinucleotide $\left(\mathrm{NAD}^{+}\right)$and its phosphate derivative - niacinamide adenosine dinucleotide phosphate (NADP). ${ }^{3}$ These cofactors and their reduced forms (NADH and NADPH) are involved in more than 40 cellular biochemical reactions, including cellular biochemistry and energy metabolism, and in the mechanisms of cell protection against ROS. ${ }^{1}$ From the clinical point of view, nicotinic acid and niacinamide are useful in the treatment of various types of diseases. It has been shown that high doses of nicotinic acid may be potent in hypercholesterolemia treatment due to the reduction of lipids, e.g., low density lipoprotein (LDL), fatty acids (FAs) or cholesterol, as well as by the increase of high density lipoprotein (HDL), ${ }^{1,4}$ On the other hand, niacinamide is a clinically attractive pharmacological agent for the prevention of type 1 diabetes mellitus due to the protection of islets. ${ }^{5}$ Likewise, Feng et al. indicated that nicotinamide may be used in the treatment of cardiac diseases and strokes as well as fetal alcohol syndrome (precursor of Bacterial NAD $\left.{ }^{+}\right) .{ }^{6}$ Moreover, niacinamide, through an increase of intercellular NADP levels, improves and stabilizes the skin barrier, and also shows strong antioxidant properties. ${ }^{7}$ The effect on the epidermal barrier function is probably associated with stimulating the differentiation of keratinocytes and/or the upregulated synthesis of ceramide and keratins. The above-mentioned factors and durability, water solubility and good penetration through the stratum corneum are the reasons why it is also widely used in sunscreens and anti-aging cosmetics. ${ }^{8}$

Ultraviolet radiation (UV) is one of the most common factors leading to skin cancer and photoaging. It is one of the major sunlight wavelengths on the light spectrum and it has been divided into 3 sections: UVC, UVB and UVA. ${ }^{9}$ UVC (wavelengths: 100-180 nm) is effectively blocked from reaching the Earth's surface by the stratospheric ozone layer of the atmosphere. As the reports indicate, exposure to UV leads to skin burns and carcinogenesis. It is widely used in germicidal lamps. UVB (wavelengths: 280-315 nm) reaches the Earth's surface in approx. 1-10\% and induces unfavorable consequences to eyes and the skin. However, it is involved in the synthesis of vitamin $\mathrm{D}_{3}$. Furthermore, the waves of UVB are absorbed by the skin with the consequence of sunburns, tanning, wrinkling or photoaging, which lead to skin cancer. UVA is not blocked by the stratospheric ozone layer and reaches the Earth's surface in approx. 90-99\%. As UVA is characterized by long wavelengths $(315-400 \mathrm{~nm})$ and low energy, it can penetrate deeper into the skin than other UV types. It causes photoaging and leads to skin cancer. However, UVA is used in medicine, in the treatment of psoriasis, and in solariums. ${ }^{9}$

Due to that, niacinamide is known as an anti-aging agent and it is characterized by many beneficial prosperities. We examined its potential protective effect against ultraviolet radiation on an in vitro cell model of fibroblasts. To our knowledge, this study for the first time demonstrated the influence of niacinamide on the main cytoskeletal proteins such as $\mathrm{F}$-actin, vimentin and $\beta$-tubulin in $\mathrm{CHO}$ AA 8 cells. Moreover, we suggested that alterations of the cytoskeletal structure can be crucial to the protective effect of this compound.

\section{Material and methods}

\section{Cell cultures and experimental treatments}

The Chinese hamster ovary cell line (CHO AA8), kindly provided by Prof. M.Z. Zdzienicka (Department of Molecular Cell Genetics, Collegium Medicum in Bydgoszcz, Nicolaus Copernicus University in Toruń, Poland), was routinely grown in Minimum Essential Medium (MEM, Lonza Group AG, Basel, Switzerland) supplemented with $10 \%$ fetal bovine serum (FBS, Gibco/Invitrogen Life Technologies, Carlsbad, CA, USA), $50 \mu \mathrm{g} / \mathrm{mL}$ gentamycin (Sigma-Aldrich Co., St. Louis, USA) and 1\% non-essential amino acids (Sigma-Aldrich). Cells were cultured in 5\% $\mathrm{CO}_{2}$, in a humidified atmosphere of $95 \%$ air, at $37^{\circ} \mathrm{C}$. For further experiments, after $80 \%$ confluence, the cells were removed by trypsin (Sigma-Aldrich) and subcultured on 6- or 12-well plates. After $24 \mathrm{~h}$ culture, the cells were treated with niacinamide (Sigma-Aldrich) at a final concentration of 1 and $10 \mathrm{mM}$ to the cell medium, or exposed to ultraviolet radiation for 5 and $15 \mathrm{~min}$. The doses of niacinamide were chosen based on the literature, while the time of UV exposure was previously described by us as inducing visible alterations in cells. ${ }^{10,11}$ In order to check the combination of both factors, first, $\mathrm{CHO}$ AA8 cells were preincubated with niacinamide for $24 \mathrm{~h}$, and next the medium was partially removed and the cells were exposed to an indicated dose of ultraviolet light at a wavelength of $254 \mathrm{~nm}$ (UV). After exposure, the incubation was continued with fresh medium and cultured for $24 \mathrm{~h}$ for the next experiments. The control cells were grown at identical conditions without treatment with niacinamide and/or UV radiation. 


\section{Based-image cytometry assay}

In order to determine cell death, the cells were stained with propidium iodide (PI) and Annexin V-Alexa Fluor ${ }^{\circledR}$ $488{\left(\text { Tali }^{\circledR}\right.}^{\circledR}$ Apoptosis Kit - Annexin V-Alexa Fluor ${ }^{\circledR} 488$ \& Propidium Iodide, Invitrogen, Thermo Fisher Scientific, Waltham, USA) according to the protocol previously described. ${ }^{12}$ The cell pellets were resuspended in an Annexin Binding Buffer (ABB) and incubated with $5 \mu \mathrm{L}$ of Annexin V-Fluor ${ }^{\circledR} 488$ (Invitrogen, Thermo Fisher Scientific) in the dark for $20 \mathrm{~min}$. Then, the cells were centrifuged at $300 \mathrm{~g} \times 5 \mathrm{~min}$ and washed with $\mathrm{ABB}$, whereupon $1 \mu \mathrm{L}$ of propidium iodide was added for $4 \mathrm{~min}$ (incubation in the dark). Finally, the stained cells were loaded into a Tali ${ }^{\circledR}$ Cellular Slides (Invitrogen, Thermo Fisher Scientific) and analyzed with a Tali ${ }^{\circledR}$ based-image cytometer (Invitrogen, Thermo Fisher Scientific) in accordance with the instruction manual. The results were analyzed on the assumption that the viable cells were characterized by negative signal for PI and Annexin V; apoptotic cells represent early and late apoptosis (all with positive signal for Annexin V-Alexa Fluor 488); necrotic cells were only PI-positive.

We measured cell cycle distribution using propidium iodide and a Tali ${ }^{\circledR}$ based-image cytometer (Invitrogen, Thermo Fisher Scientific). ${ }^{12}$ The CHO AA8 cells were harvested by trypsin and fixed with ice-cold $70 \%$ ethanol in distillated water, and stored at $-20^{\circ} \mathrm{C}$ for a few days. Afterwards, the cells were centrifuged at $650 \mathrm{~g} \times 7 \mathrm{~min}$, and were then rinsed with $1 \mathrm{~mL}$ of cold phosphate buffered saline (PBS) and centrifuged at $500 \mathrm{~g} \times 5 \mathrm{~min}$. Subsequently, the cell pellets were resuspended in $\mathrm{Tali}^{\circledR}$ Cell Cycle Kit (Invitrogen, Thermo Fisher Scientific) and incubated in the dark for $30 \mathrm{~min}$. The Tali ${ }^{\circledR}$ cell cycle program was used to determine the fractions of cells in the sub-G1, G2/M, S, G0/G1 phases from the cell cycle distribution.

Each experiment was repeated in triplicate, and the results were analyzed using FCS Express 4 Plus Researches Edition (deNovo Software, v. 4.03; Glendale, CA, USA).

\section{Fluorescence staining of cytoskeletal proteins}

To understand the protective mechanism of niacinamide, alterations in the main cytoskelatal proteins were analyzed. The CHO AA8 cells were cultured on the coverslips. First, in order to perform fluorescence staining of $\beta$-tubulin (microtubules), the cells were fixed in 3,3'-dithiodipropionic acid (DTSP) (Sigma-Aldrich Co.), diluted in microtubule-stabilizing buffer (MTSB) (1 mM EGTA, $10 \mathrm{mM}$ PIPES, 4\% polyethylene glycol); Sigma-Aldrich Co.; 1:50, $10 \mathrm{~min}$ at room temperature (RT), and were washed with DTSP in 0,5\% Triton X-100 in MTSB (TSB) (1:50, $10 \mathrm{~min}, \mathrm{RT})$. Next, the cells were permeabilized with Triton-X 100 (Serva, Heidelberg, Germany) in TSB (10 min, RT) and incubated with $4 \%$ paraformaldehyde (PFA) (Serva) in HBSS (Hanks' Balanced
Salt Solution, Sigma-Aldrich Co.) for $20 \mathrm{~min}$ at RT. Then, the CHO AA8 cells were rinsed in PBS $(3 \times 5 \mathrm{~min}, \mathrm{RT})$ and blocked in $1 \%$ bovine serum albumin (BSA)-PBS (15 min, RT). In turn, for fluorescence staining of vimentin and F-actin (intermediate filaments and microfilaments, respectively), the material was fixed in $4 \% \mathrm{PFA}(20 \mathrm{~min}, \mathrm{RT})$, rinsed with PBS $(3 \times 5 \mathrm{~min}, \mathrm{RT})$ and blocked in $1 \% \mathrm{BSA}$ in PBS (15 min, RT). Afterwards, the CHO AA8 cells were incubated with the primary antibody special for vimentin (Sigma-Aldrich) and $\beta$-tubulin (Sigma-Aldrich) at a dilution 1:60 and 1:80 in 1\% BSA-PBS, respectively (1 h, RT). After the series of washes with PBS $(3 \times 5 \mathrm{~min}, \mathrm{RT})$, the secondary antibody tetramethylrhodamine (TRITC) anty-mouse IgG (Sigma-Aldrich Co.) was used (1:85 in PBS, 1 h, RT). In order to visualize microfilaments (F-actin), the cells were incubated with Alexa Fluor $488^{\circledR}$ conjugated with phalloidin (Invitrogen, Thermo Fisher Scientific, Molecular Probes; 1:40 in PBS, 20 min, RT). Next, the nuclei of cells were stained by 4',6-diamidyno-2-fenyloindol (DAPI) (Sigma-Aldrich Co.; 1:20000 in PBS, 10 min, RT) and after the final rinse with PBS, the slides were mounted in Aqua-Poly/Mount (Polysciences Inc., Warrington, USA). The fluorescence analysis was performed using the Nikon Eclipse E800 fluorescence microscope (Nikon, Tokyo, Japan) and NIS-Elements 4.0 software (Nikon).

\section{Assessment of ultrastructural alterations}

In order to assess the ultrastructural alterations, a transmission electron microscope was used. After the cells were cultured, the material was fixed with $3.6 \%$ glutaraldehyde (Polyscience, Warrington, PA, USA) in $0.1 \mathrm{M}$ sodium cacodylate buffer (Roth, Karlsruhe, Germany) for $30 \mathrm{~min}$ at RT and rinsed with $0.1 \mathrm{M}$ cacodylate buffer ( $\mathrm{pH}$ 7.4). Then, following the use of $1 \%$ osmium tetroxide in cacodylate buffer (1 h, RT), the CHO AA8 cells were washed with $0.1 \mathrm{M}$ cacodylate buffer and dehydrated through a graded series of alcohols (30-90\%) and acetone (90-100\%). Subsequently, the study material was embedded in Epon 812 (Roth), and polymerization of the resin occurred for a few days $\left(24 \mathrm{~h}\right.$ at $37^{\circ} \mathrm{C}$ and $120 \mathrm{~h}$ at $65^{\circ} \mathrm{C}$ ). Afterwards, the parts of the material selected were cut into ultra-thin sections using a Reichert Om-U3 ultra-microtome (Vienna, Austria), placed on copper grids and stained with $1 \%$ uranyl acetate. The prepared material was examined using a JEM-100CX electron microscope (Jeol, Tokyo, Japan).

\section{Statistical analysis}

Statistical comparisons between the 2 groups of cell death and cell cycle data were performed using a 2-tailed Mann-Whitney U test. Differences between the groups were considered significant when $\mathrm{p}<0.05$. GraphPad Prism 5.0 (GraphPad Software, San Diego, CA, USA) was used for the statistical analyses. 


\section{Results}

\section{Effect of niacinamide and/or UV on cell death}

We studied the occurrence of cell death of $\mathrm{CHO}$ AA8 cells with treatment by various concentrations of niacinamide, different time of exposure to UV, and their combination. The analysis of cell death was performed using a Tali ${ }^{\circledR}$ Image-based cytometer, following Annexin V-Alexa
Fluor $488^{\circledR}$ and Propidium Iodide double staining. The representative plots were presented in Fig. $1 \mathrm{~A}$ and the mean percentage of results is presented in Table 1 . In the $\mathrm{CHO}$ AA8 cells, no statistically significant differences in the percentage of live and apoptotic cells were observed following the treatment with all niacinamide doses as compared to the control. However, the exception was statistically significant increase in the percentage of Annexin V-positive cells after incubation with niacinamide at $10 \mathrm{mM}$ concentration. In turn, the data demonstrated that

Table 1. The mean percentage of cell death results

\begin{tabular}{|c|c|c|c|c|c|c|c|c|c|}
\hline Cells groups & $\begin{array}{l}\text { CTRL } \\
24 \mathrm{~h}\end{array}$ & $1 \mathrm{mM} \mathrm{Niac}$ & 10 mM Niac & $5 \mathrm{~min}$ UV & $15 \mathrm{~min}$ UV & $\begin{array}{c}1 \mathrm{mM} \mathrm{Niac/} \\
5 \mathrm{~min} \text { UV }\end{array}$ & $\begin{array}{c}1 \mathrm{mM} \mathrm{Niac/} \\
15 \mathrm{~min} \text { UV }\end{array}$ & $\begin{array}{c}10 \mathrm{mM} \mathrm{Niac/} \\
5 \mathrm{~min} \text { UV }\end{array}$ & $\begin{array}{c}10 \mathrm{mM} \mathrm{Niac/} \\
15 \mathrm{~min} \text { UV }\end{array}$ \\
\hline IP-/A- & 95.63 & 93.68 & 93 & $87.01^{*}$ & $75.08^{*}$ & 93.49 & 91.44 & 93.87 & $87.89^{*}$ \\
\hline IP-/A+ & 1.78 & 2.57 & $5.19 *$ & $10.61^{*}$ & $25.5^{*}$ & $5.29 *$ & $5.8^{*}$ & 2.31 & 3.92 \\
\hline IP+/A- & 2.01 & 2.53 & 2.14 & 3.58 & 1.41 & 3.95 & 4.11 & 2.36 & $7.72^{*}$ \\
\hline
\end{tabular}

* Statistically significant results in comparison to the control $(p<0.05)$; CTRL - control; Niac - niacinamide; UV - ultraviolet.

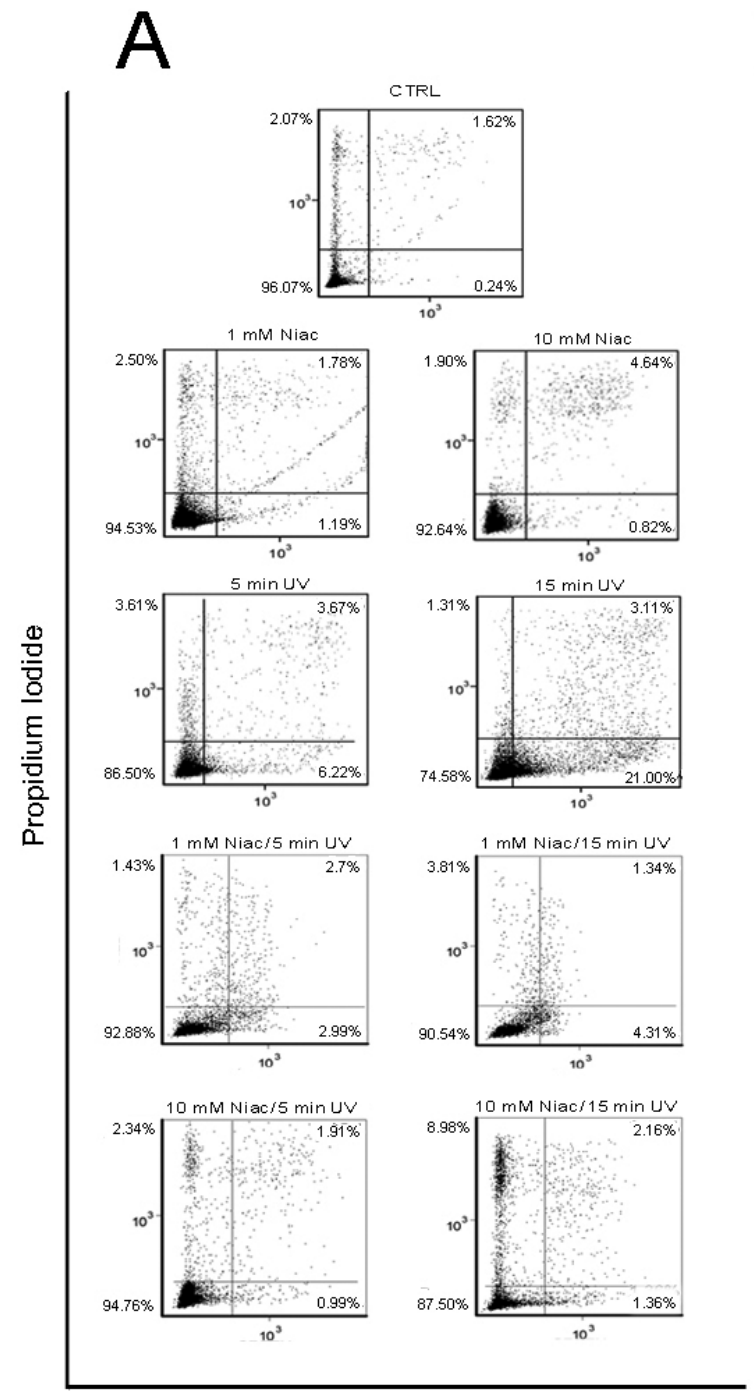

Annexin V-Alexa Fluor 488
B
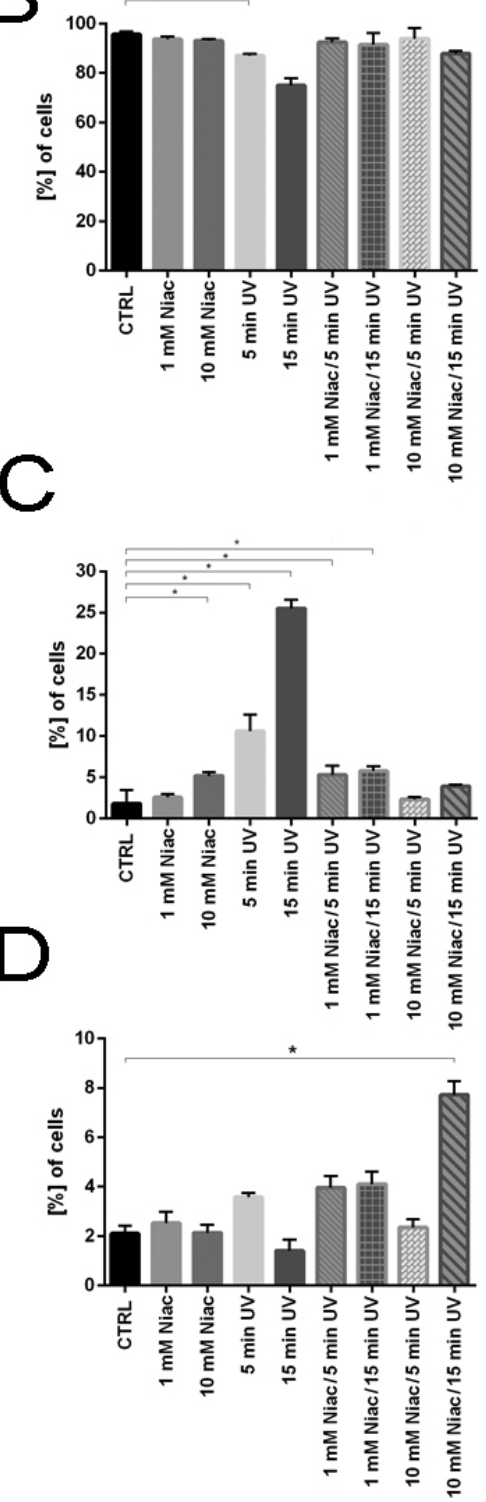

Fig. 1. Based-image cytometric analysis of cell death using Annexin V-Alexa Fluor 488 and PI assay

A - representative plots;

$\mathrm{B}$ - the percentage of viable cells; C - the percentage of apoptotic cells;

$D$ - the percentage of necrotic cells. The cells were treated with different concentration of niacinamide (1 and $10 \mathrm{mM}$ ) for $24 \mathrm{~h}$, exposed to 5 and 15 min UV, and with both factors combined; asterisks indicate statistically significant differences from control cells $(p<0.05)$. 
ultraviolet radiation decreased the mean percentage of viable cells in time-dependent manner from $87.01 \%$ for $5 \mathrm{~min}$ to $75.08 \%$ for $15 \mathrm{~min}$. Besides, we showed that the population of apoptotic cells ranged from $10.61 \%$ following $5 \mathrm{~min}$ of UV radiation to $25.5 \%$ after 15 min exposure to UV. In addition, the $\mathrm{CHO}$ AA8 cells exposed to ultraviolet irradiation resulted in a statistically significant decrease of cell viability, thereby leading to the statistically significant increase of apoptotic cells in comparison to untreated cells (Fig. $1 \mathrm{~B}-\mathrm{D}$ ).

As shown in Fig. 1 B, after combined treatment with niacinamide and UV radiation, we did not observe statistically significant differences of cell viability in comparison to control, except for $10 \mathrm{mM} \mathrm{Niac} / 15 \mathrm{~min} \mathrm{UV}$, whereas the mean percentage of live cells was $87.89 \%$. Furthermore, following treatment with $1 \mathrm{mM} \mathrm{Niac} / 5 \mathrm{~min} U V$ and $1 \mathrm{mM}$ Niac/15 min UV, the Annexin V staining showed statistically significant differences in the population of apoptotic cells in comparison to untreated cells (from 1.78\% for control to $5.29 \%$ and $5.8 \%$, respectively). The data demonstrated that preincubation with increasing doses of niacinamide and exposure for UV resulted in a statistically significant increase in the mean percentage of viable cells (excepting $10 \mathrm{mM} \mathrm{Niac} / 5 \mathrm{~min} \mathrm{UV}$ ) in comparison to the results following only UV radiation, thus reducing the Annexin V-positive population of cells (Fig. 1 B, C).

\section{Cell cycle redistribution following the treatment with niacinamide and/or UV}

During the project, the effect of the treatment with niacinamide and/or UV radiation on the cell cycle of $\mathrm{CHO}$ AA8 cell line was examined. Propidium iodide (PI) staining and an image-based cytometric analysis were used to determine cell cycle distribution and the results are shown in Fig. 2 and Table 2. Our data presented that the incubation with $1 \mathrm{mM}$ and $10 \mathrm{mM}$ niacinamide led to an increase in the cell population of sub-G1 phase (Fig. 2 A). In turn, proportions of cells in sub-G1 phase increased from $4.83 \%$ (control) to $12.78 \%$ (5 min) and $29.01 \%$ (15 min) following UV radiation in a time-dependent manner. As regards the population of cells in sub-G1, after co-incubation with chosen doses of niacinamide and exposure to UV, there was a statistically significant increase in comparison with the population of control cells (Fig. 2 A). Nevertheless, we observed a statistically significant decrease in the mean percentage of cells classified as G2/M in comparison with the control as a consequence of treatment with all doses of niacinamide, both the exposure times of ultraviolet radiation and all combinations of these factors (Fig. 2 B). Concurrently, there were non-statistical differences in the population of cells categorized as S phase when compared with untreated cells excepting the cells treated with $1 \mathrm{mM}$ niacynamide and exposed to UV light for $15 \mathrm{~min}$ (decrease

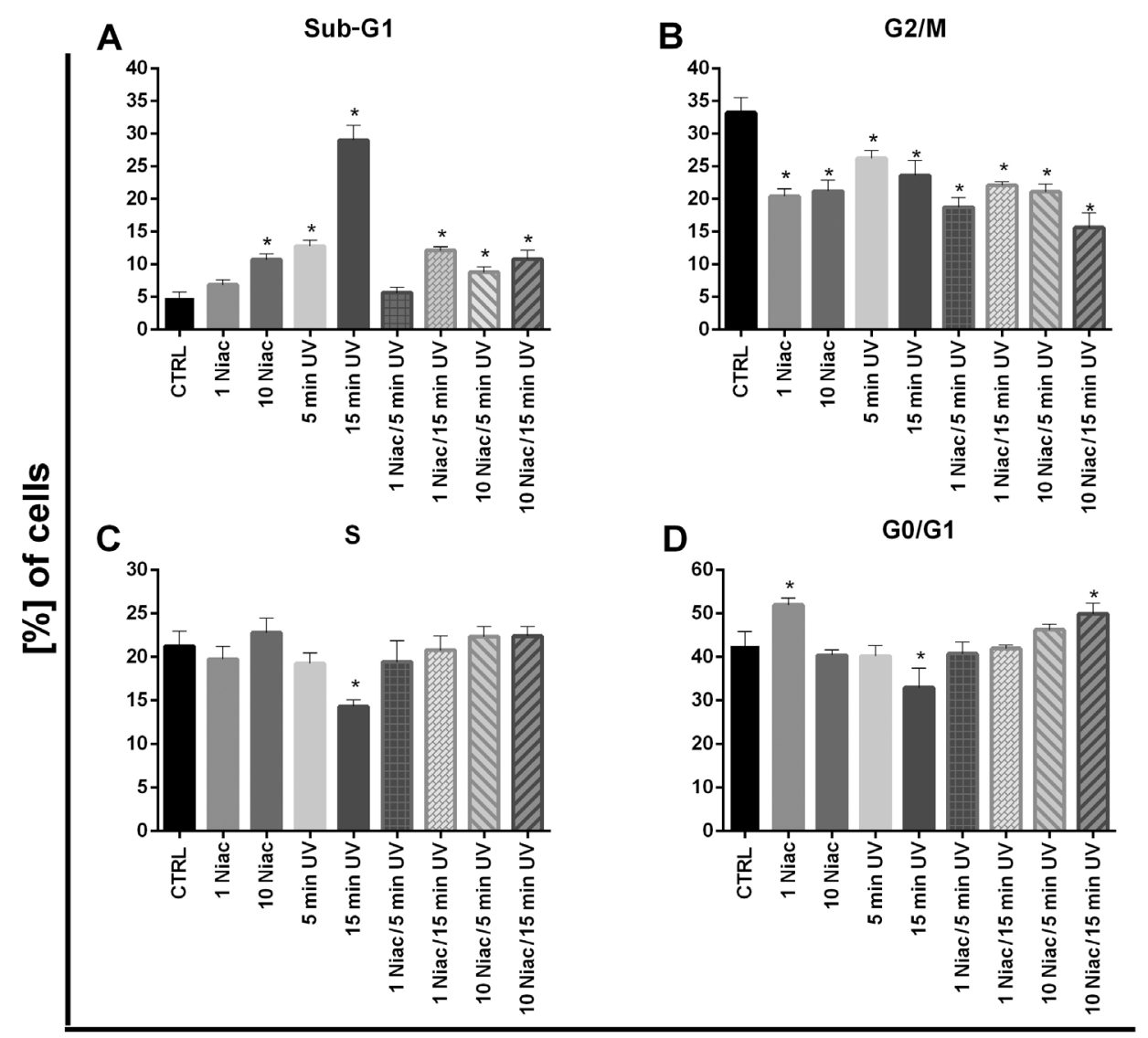

Fig. 2. Based-image cytometric analysis of cell cycle distribution in $\mathrm{CHO}$ AA8 cells treated with different concentrations of niacinamide ( 1 and $10 \mathrm{mM}$ ) for $24 \mathrm{~h}$, exposed to 5 and 15 min of UV, coincubated with Niac, and next exposed to UV

The percentage of cells in: $A$ - sub-G1 phase; $\mathrm{B}$ - G2/M phase; C - S phase; D - with G0/G1 DNA content; asterisks indicate statistically significant differences from control cells $(p<0.05)$. 
Table 2. The mean percentage of cell cycle distributions

\begin{tabular}{|c|c|c|c|c|c|c|c|c|c|}
\hline Cells groups & $\begin{array}{l}\text { CTRL } \\
24 \mathrm{~h}\end{array}$ & $1 \mathrm{mM} \mathrm{Niac}$ & $10 \mathrm{mM}$ Niac & $5 \mathrm{~min}$ UV & $15 \mathrm{~min}$ UV & $\begin{array}{l}1 \mathrm{mM} \mathrm{Niac/} \\
5 \mathrm{~min} \text { UV }\end{array}$ & $\begin{array}{c}1 \mathrm{mM} \mathrm{Niac/} \\
15 \mathrm{~min} \text { UV }\end{array}$ & $\begin{array}{l}10 \mathrm{mM} \mathrm{Niac} / \\
5 \mathrm{~min} \mathrm{UV}\end{array}$ & $\begin{array}{c}10 \mathrm{mM} \mathrm{Niac} / \\
15 \mathrm{~min} \text { UV }\end{array}$ \\
\hline Sub-G1 & 4.83 & 6.86 & $10.73^{*}$ & $12.78^{*}$ & $29.01^{*}$ & 5.64 & $12.10^{*}$ & $8.79 *$ & $10.83^{*}$ \\
\hline $\mathrm{G} 2 / \mathrm{M}$ & 33.24 & $20.42^{*}$ & $21.21^{*}$ & $26.24^{*}$ & $23.63^{*}$ & $18.74^{*}$ & $22.10^{*}$ & $21.13^{*}$ & $15.64^{*}$ \\
\hline S & 21.26 & 19.77 & 22.79 & 19.27 & $14.32^{*}$ & 19.45 & 20.79 & 22.33 & 22.40 \\
\hline G0/G1 & 42.57 & $51.98^{*}$ & 40.44 & 40.21 & $32.97^{*}$ & 40.79 & 41.98 & 46.29 & $49.92^{*}$ \\
\hline
\end{tabular}

* Statistically significant results in comparison to the control $(p<0.05)$; CTRL - control; Niac - niacinamide; UV - ultraviolet.

to $14.32 \%$ ) (Fig. 2 C). Similarly, a statistically significant decrease in the proportions of cells in G0/G1 phase was detected after 15 min of ultraviolet radiation. On the other hand, we also observed that the $\mathrm{CHO}$ AA8 cells treated with $1 \mathrm{mM}$ Niac and $10 \mathrm{mM} \mathrm{Niac} / 15 \mathrm{~min}$ UV were characterized by a statistically significant increase in G0/G1 phase population. Moreover, as shown in Fig. $2 \mathrm{D}$, the median percentage of cells in G0/G1 was at a similar level as in the case of control cells.

\section{Fluorescence staining} of the main cytoskeletal proteins

Morphological changes of cytoskeleton architecture depended on the times and doses of factors. The control cells were characterized by oval nuclei, regular shape, size and numerous actin stress fibers, typical for fibroblasts (Fig. 3 A). After $24 \mathrm{~h}$ of niacinamide treatment, the cells
CTRL

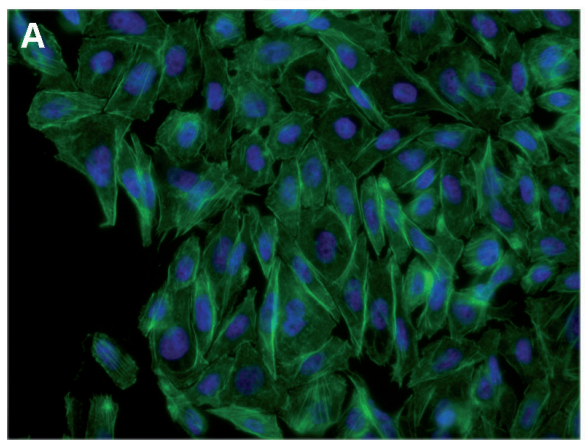

5 min UV

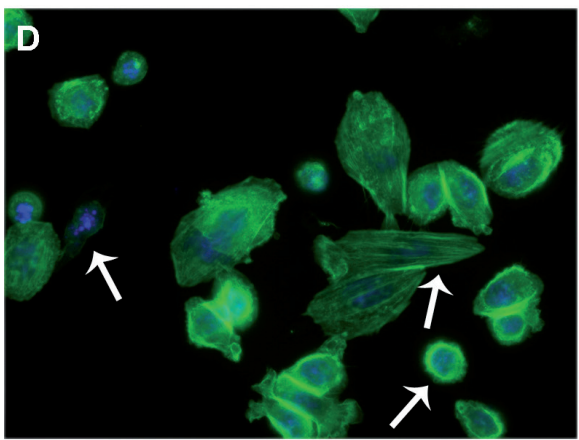

1 Niac/15 min UV

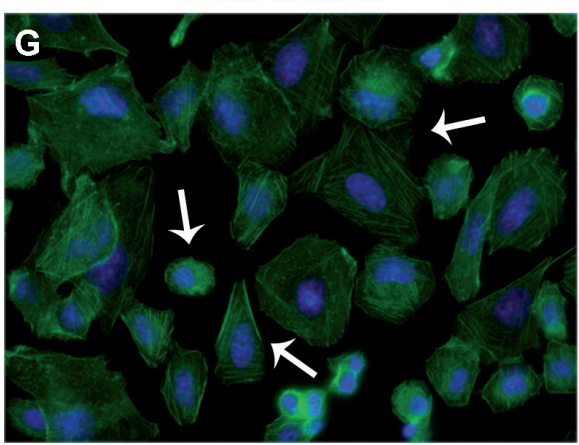

1 Niac

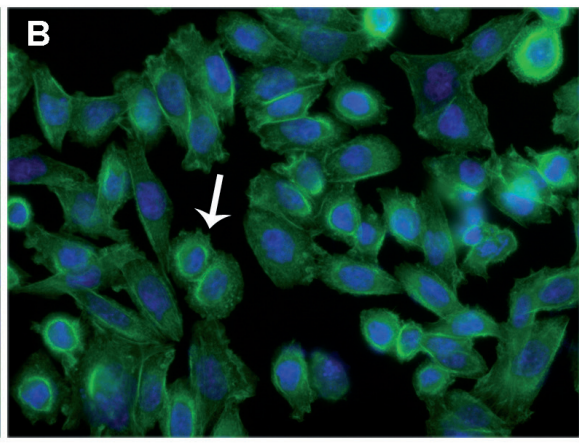

15 min UV

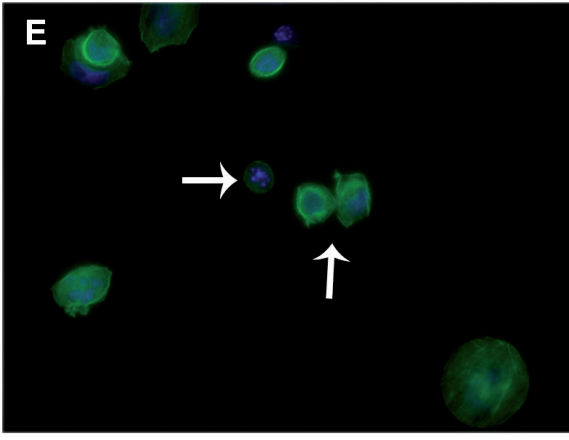

$10 \mathrm{Niac} / 5 \mathrm{~min}$ UV

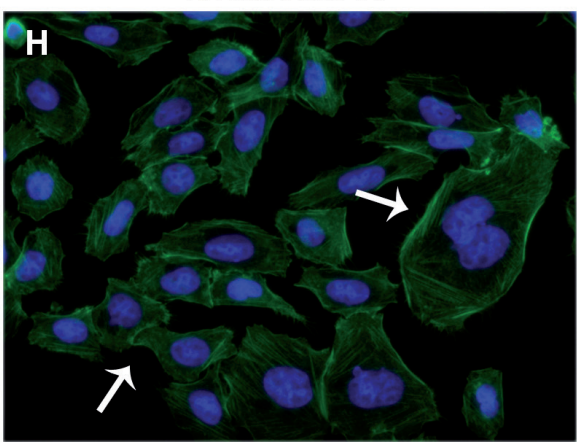

10 Niac

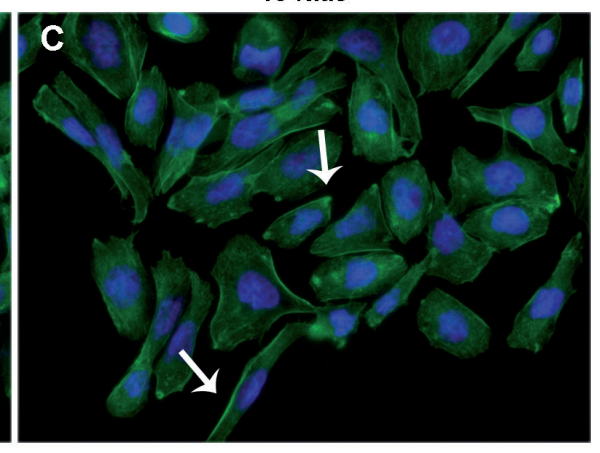

$1 \mathrm{Niac} / 5$ min UV

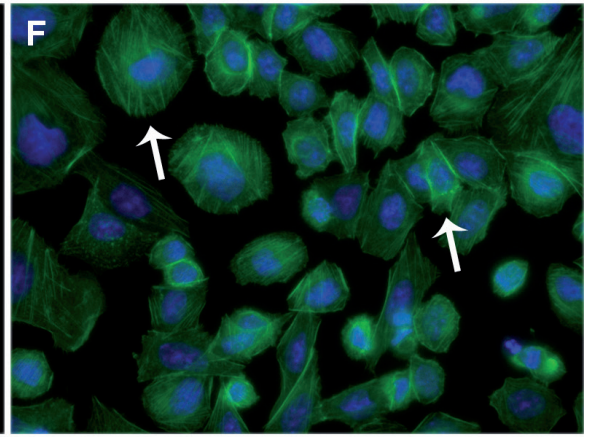

10 Niac/15 min UV

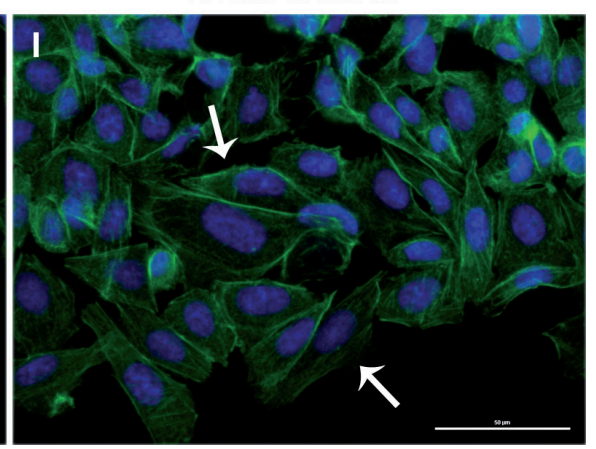

Fig. 3. CHO AA8 cells stained for F-actin; cell nuclei labeled with DAPI

A - control cells; B - cells treated with $1 \mathrm{mM}$ of niacinamide; C - cells treated with $10 \mathrm{mM}$ of niacinamide; D - cells exposed to $5 \mathrm{~min}$ UV; $\mathrm{E}$ - cells exposed to $15 \mathrm{~min}$ UV; the combination of both factors: F - $1 \mathrm{mM} \mathrm{Niac} / 5 \mathrm{~min} U \mathrm{~V} ; \mathrm{G}-1 \mathrm{mM} \mathrm{Niac} / 15 \mathrm{~min}$ UV; H - $10 \mathrm{mM} \mathrm{Niac/5} \mathrm{min}$ UV; I - $10 \mathrm{mM} \mathrm{Niac/15} \mathrm{min}$ UV; Bar $=50 \mu \mathrm{m}$. 
CTRL

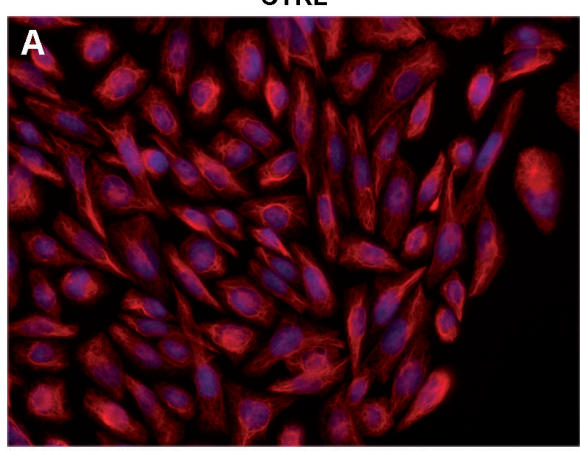

5 min UV

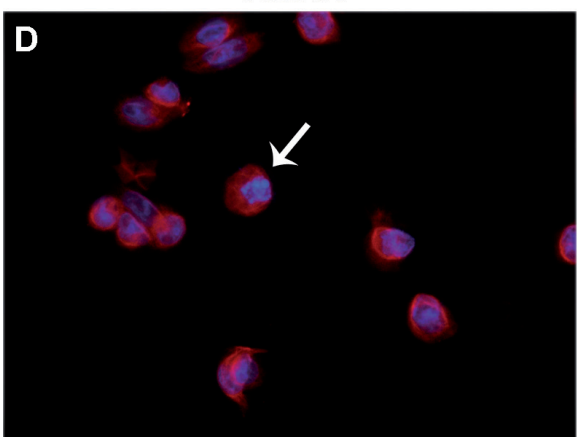

$1 \mathrm{Niac} / 15$ min UV

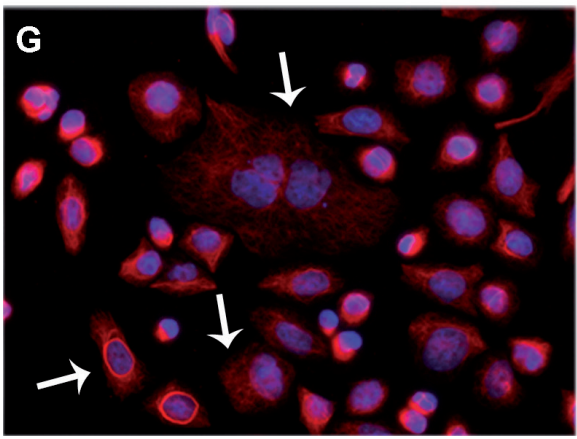

1 Niac

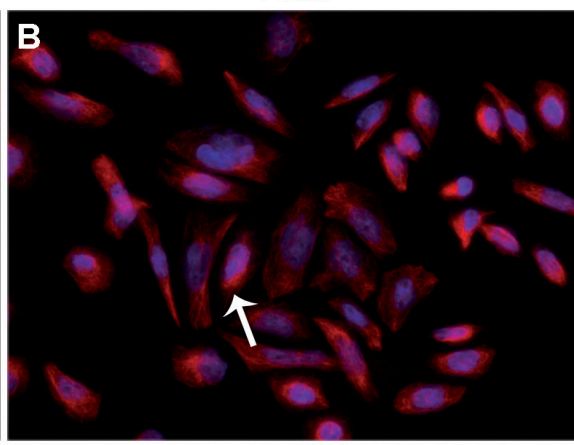

$15 \min$ UV

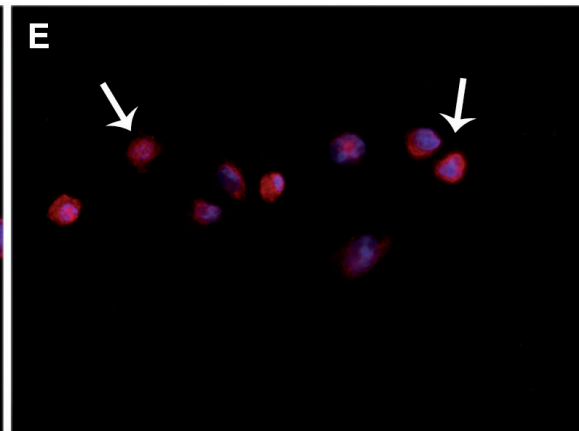

$10 \mathrm{Niac} / 5$ min UV

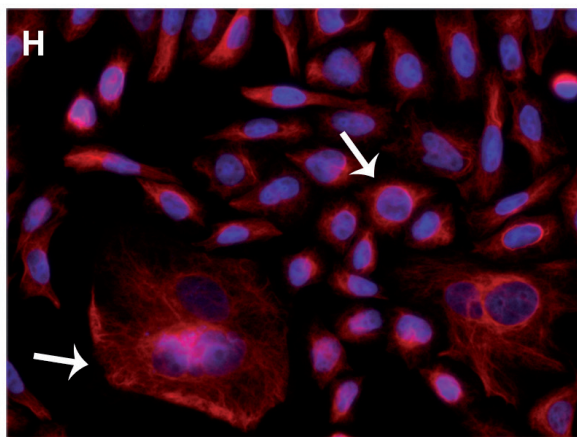

10 Niac

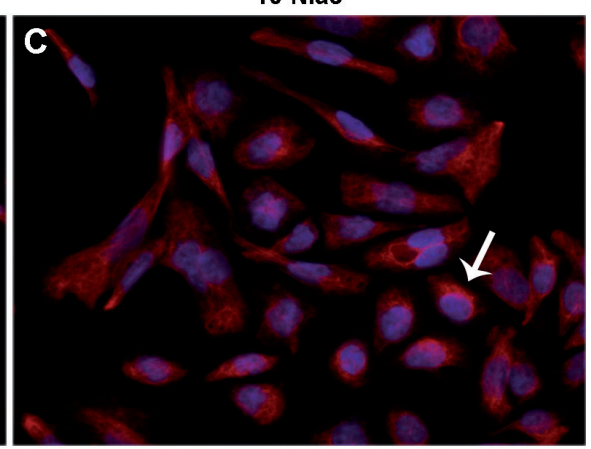

$1 \mathrm{Niac} / 5 \mathrm{~min}$ UV

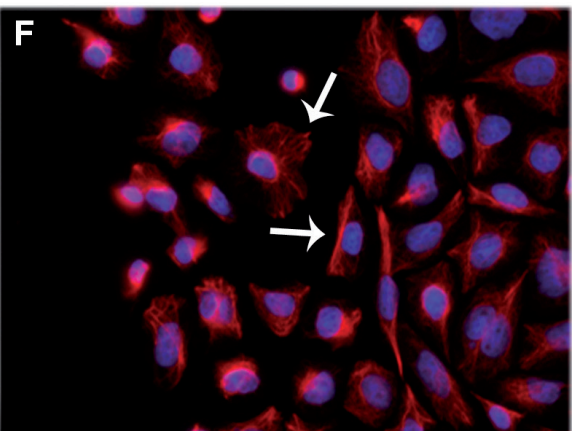

$10 \mathrm{Niac} / 15 \mathrm{~min}$ UV

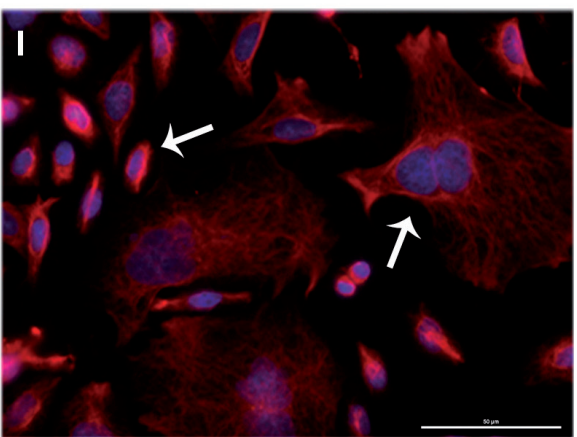

Fig. 4. CHO AA8 cells stained for vimentin (intermediate filaments); cell nuclei labeled with DAPI

A - control cells; B - cells treated with $1 \mathrm{mM}$ of niacinamide; C - cells treated with $10 \mathrm{mM}$ of niacinamide; D - cells exposed to $5 \mathrm{~min} U \mathrm{~V}$; $\mathrm{E}$ - cells exposed to $15 \mathrm{~min}$ UV; the combination of both factors: F- $1 \mathrm{mM} \mathrm{Niac} / 5 \mathrm{~min} U V ; \mathrm{G}-1 \mathrm{mM} \mathrm{Niac} / 15 \mathrm{~min} U \mathrm{~V} ; \mathrm{H}-10 \mathrm{mM} \mathrm{Niac} / 5 \mathrm{~min}$ UV; I - $10 \mathrm{mM} \mathrm{Niac} / 15 \mathrm{~min}$ UV; Bar $=50 \mu \mathrm{m}$.

possessed actin filaments in the perinuclear area and intensive fluorescence of F-actin in the cortical part of the cell, like in untreated cells (Fig. 3 B, C). In turn, according to our previous results (cell death analysis), we noticed shrunk cells with depolymerization of the actin network following UV irradiation. After $5 \mathrm{~min}$ of ultraviolet exposure, F-actin formed a ring-like structure around the nucleus. However, in the enlarged cells, the actin network was expanded (Fig. 3 D). Following exposure of $15 \mathrm{~min}$, strong F-actin rearrangement was observed in most of shrunk cells (Fig. $3 \mathrm{E}$ ). The assessment of F-actin structure showed that in the case of following groups - $1 \mathrm{mM}$ Niac/5 min UV and $1 \mathrm{mM} \mathrm{Niac/15}$ min UV numerous stress fibres were clearly visible (Fig. 3 F, G). The cells co-treated with higher concentration of niacinamide $(10 \mathrm{mM})$ and next exposed to UV had a voluminous actin network and contained more bundles of stress fibers, especially in the enlarged cells (Fig. 3 H, I). Furthermore, fluorescence staining of microfilaments showed their accumulation in the cortical part and at the border between neighboring cells (Fig. 3 F-I).

In turn, in control cells, vimentin and microtubules were well-developed and were characterized by regular scaffold of thin filaments (Fig. 4 A, 5 A). Our cytoskeletal studies revealed that after exposure of the $\mathrm{CHO} A \mathrm{AA} 8$ cells to niacinamide, a network of intermediate filaments was regular and there appeared some cells with intensity labeling of vimentin in the nuclear area (Fig. 4 B, C). Similar to the observation of F-actin, the image of 5 and 15 min exposure of UV showed the large population of apoptotic cells which were characterized by rounded shape, shrunk nuclei and strong reorganization of vimentin bundles (Fig. 4 D, E). Following treatment with combination of all doses of niacinamide and both the exposure times of UV irradiation, our observation revealed that part of cells possessed thick vimentin bundles in perinculear region (Fig. 4 F-I). 


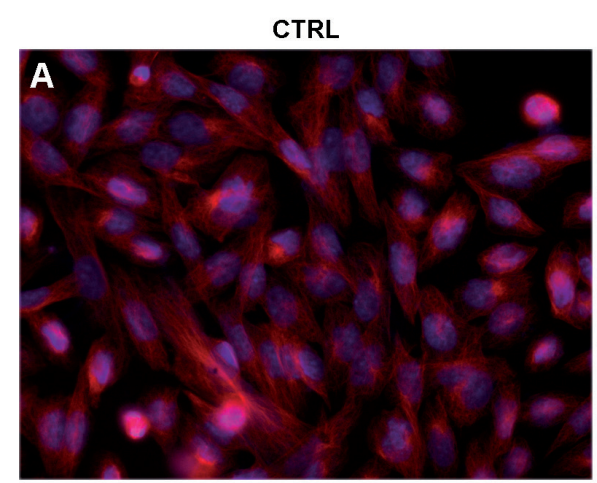

5 min UV

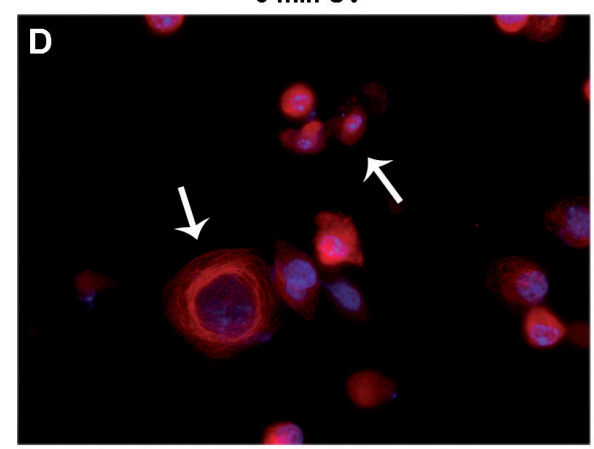

$1 \mathrm{Niac} / 15 \mathrm{~min}$ UV

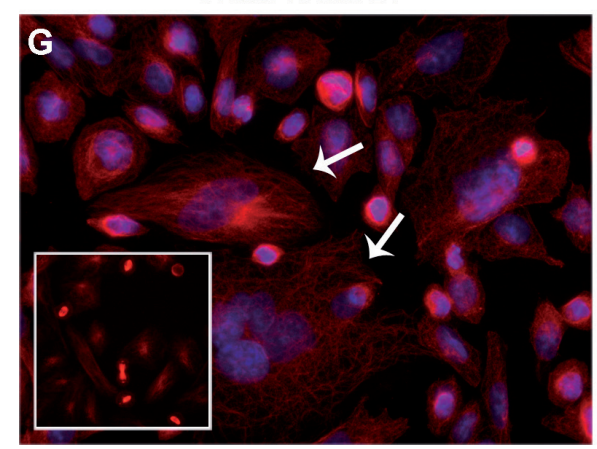

1 Niac

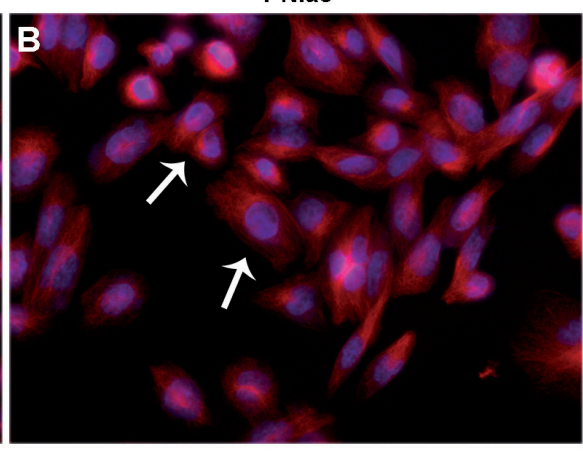

15 min UV

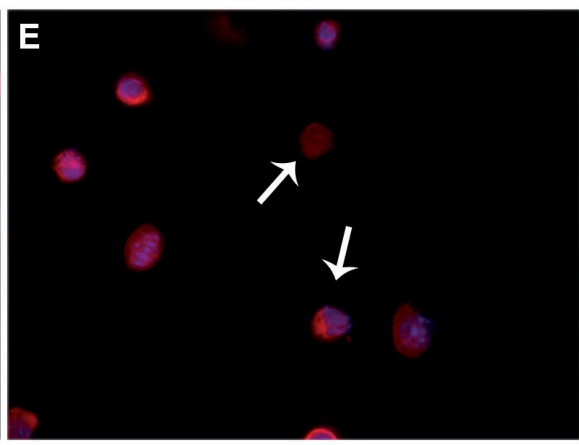

$10 \mathrm{Niac} / 5 \mathrm{~min}$ UV

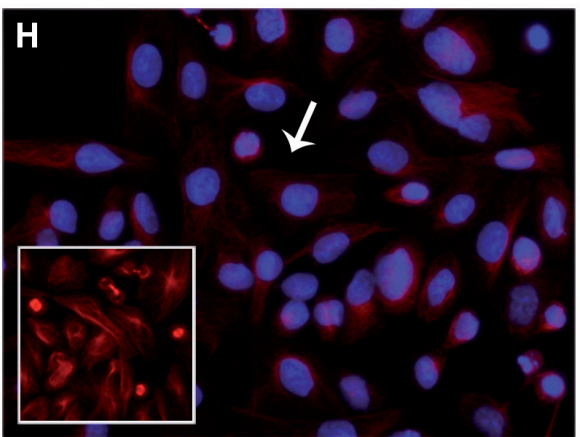

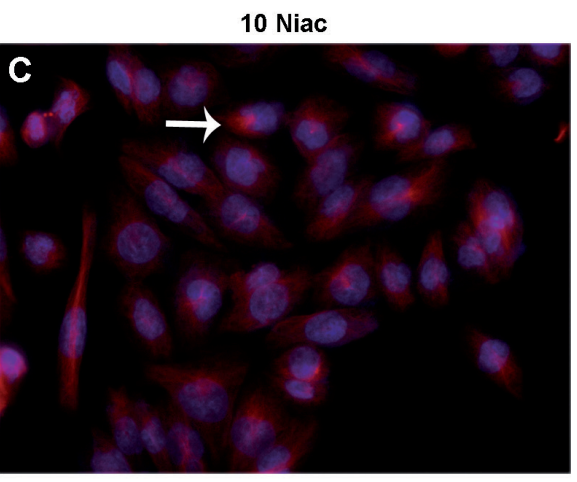

$1 \mathrm{Niac} / 5$ min UV

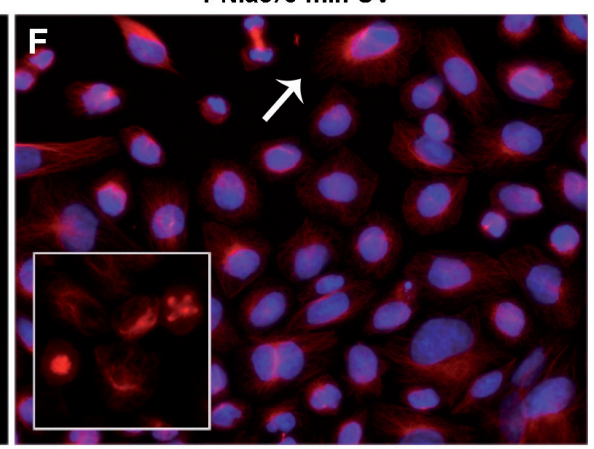

$10 \mathrm{Niac} / 15$ min UV

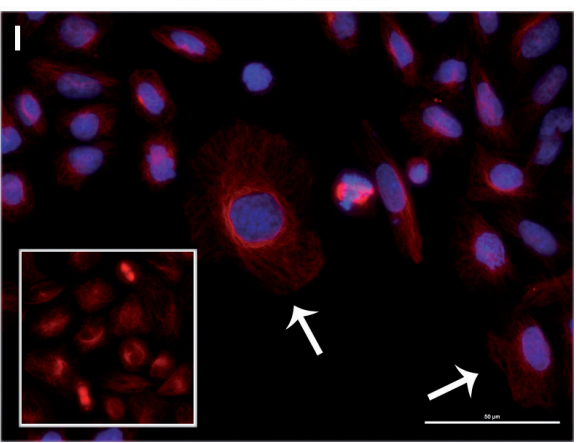

Fig. 5. CHO AA8 cells stained for $\beta$-tubulin (microtubules); cell nuclei labeled with DAPI

A - control cells; B - cells treated with $1 \mathrm{mM}$ of niacinamide; C - cells treated with $10 \mathrm{mM}$ of niacinamide; D - cells exposed to $5 \mathrm{~min}$ UV; E - cells exposed to $15 \mathrm{~min}$ UV; the combination of both factors: F - $1 \mathrm{mM} \mathrm{Niac} / 5 \mathrm{~min}$ UV; G - $1 \mathrm{mM} \mathrm{Niac} / 15 \mathrm{~min}$ UV; H - $10 \mathrm{mM} \mathrm{Niac/5} \mathrm{min} \mathrm{UV;} \mathrm{I} \mathrm{-} 10 \mathrm{mM} \mathrm{Niac/15} \mathrm{min}$ UV; Bar $=50 \mu \mathrm{m}$.

Furthermore, we also observed the small population of shrunken cells with strongly labeled of vimentin in the nucleus area and some enlarged cells, where the network of intermediate filaments were strongly extended (Fig. 4 G-I).

As shown in Fig. 5 ( $\beta$-tubulin staining), following treatment with different concentrations of Niac, the population of altered cells was very small. Some $\mathrm{CHO}$ AA8 cells were characterized by strongly labeled $\beta$-tubulin localized in the perinuclear region, and some enlarged cells presented thick microtubules (Fig. 5 B, C). Additionally, we observed that $\mathrm{UV}$ radiation promoted changes in the distribution of main cytoskeletal protein such as $\beta$-tubulin in the CHO AA8 cells. The shorter time of UV exposure led to a high concentration of microtubules as ring-like structure in the perinuclear area. Furthermore, the cells presenting thick $\beta$-tubulin were occasionally also observed. Besides, fluorescence microscopic observation of microtubules demonstrated that the longer time of UV radiation (15 $\mathrm{min}$ ) resulted in reorganization of $\beta$-tubulin, especially in apoptotic cells (Fig. 5 D, E). An interesting fact worth emphasizing is that after exposure of the CHO AA8 cells to all combinations of chosen factors, we observed a cell population with a visible mitotic spindle (Fig. 5 F-I inserts). Moreover, as shown in Fig. 5 F-I, a strongly expanded network of tubulin with thick bundles was noticed in most of the enlarged cells. After the higher dose of Niac (10 mM) and time of UV exposure (15 min), the higher labeling of $\beta$-tubulin in the perinuclear region was seen (Fig. 5 I).

Furthermore, compared to untreated CHO AA8 cells, treatment with both niacinamide and UV radiation caused the alterations in cell shape from spindle type, typical for fibroblasts, to more rounded and flattened. Also, microscopic observation revealed a smaller population of cells with hallmarks characteristics for apoptosis, such as shrinkage of the cells or chromatin condensation, than in the case of ultraviolet exposure alone. 


\section{Alterations at the ultrastructural level}

The last step of our studies was the ultrastructure analysis of the CHO AA8 cells cultured with niacinamide, exposed to different time of UV and treated with both factors. The alterations were performed using a transmission electron microscope (TEM) and these methods confirmed our previous observations. Namely, the control cells possessed a regular shape and an oval single nucleus (Fig. 6 A). TEM revealed that treatment with niacinamide resulted in the presence of some giant cells and cells with swollen mitochondria or a small amount of vacuoles, probably cantained fine fibrillar material. Nevertheless, a population of these cells did not show significant morphological differences in comparison with the untreated cells (Fig. $6 \mathrm{~B}, \mathrm{C}$ ). In turn, following the exposure to ultraviolet radiation, the cells were characterized by visible morphological changes in the nucleus area and cytoplasm. After 5 min of UV radiation, the alterations were related to the marginalization of chromatin and segmented/lobulated nuclei (Fig. 6 D). Besides, some UV-irradiated cells (15 min) presented acute damage manifestation and they included a degenerated cytoplasm and/or extensive cytoplasmic vacuolization, swollen and disturbed mitochondria, and shrunk nuclei with a high condensation of chromatin (Fig. 6 E). On the other hand, electron micrographs of the CHO AA8 cells treated with both niacinamide and UV rays showed no dramatic changes in size and shape of cells in comparison to the population of untreated cells. We only observed an irregular shape of nucleus (segmented) with visible nucleolus, especially in the cells following $1 \mathrm{mM} \mathrm{Niac} / 15 \mathrm{~min}$ UV and $10 \mathrm{mM}$ Niac/5 min UV (Fig. 6 G, H), whereas, as showed in Fig. 6 F, I, significant changes in the ultrastructure of the $\mathrm{CHO}$ AA8 cells were not clearly observed.

\section{Discussion}

$\mathrm{UV}$ radiation is involved in many different harmful processes in cells. It has been reported that UV exposure results in the formation of cyclobutane-pyrimidine dimers (CPDs) and 6-4 photoproducts (6-4 PPs), which evoke the most abundant cytotoxic and mutagenic DNA lesions. ${ }^{13}$ Rastogi et al. have described a number of biological effects
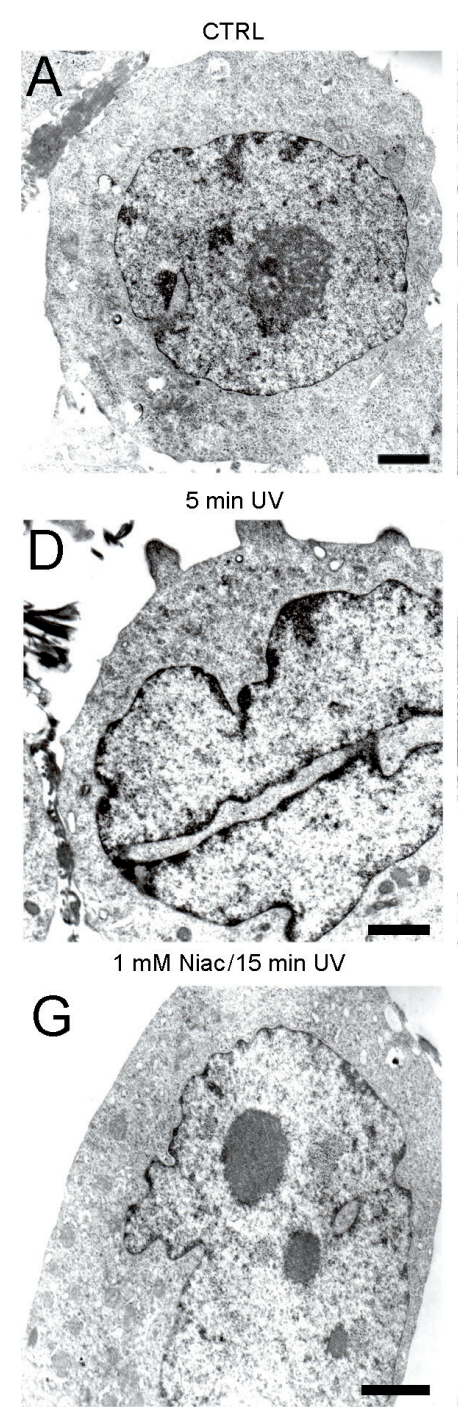
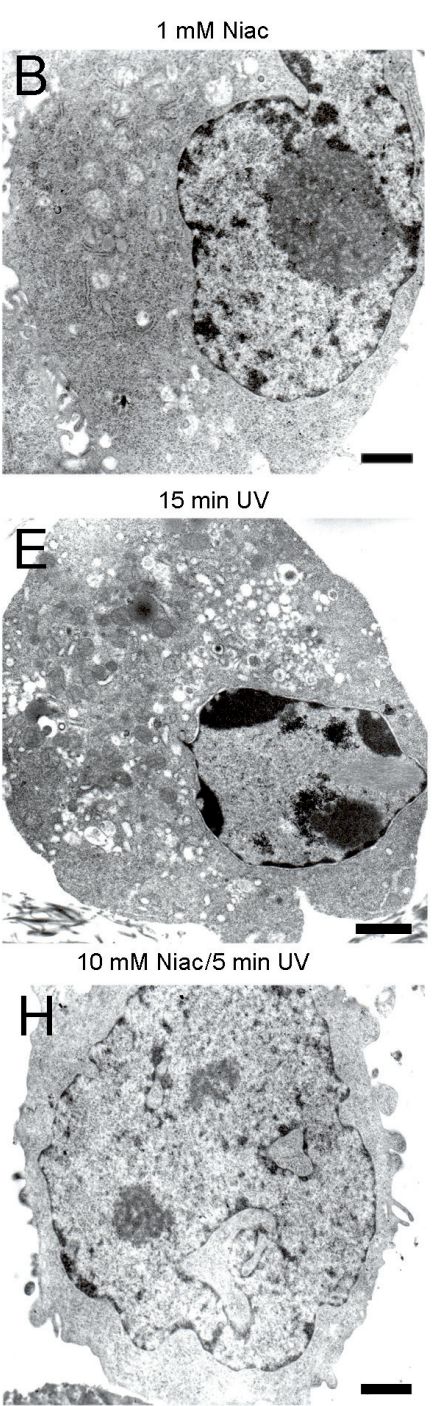
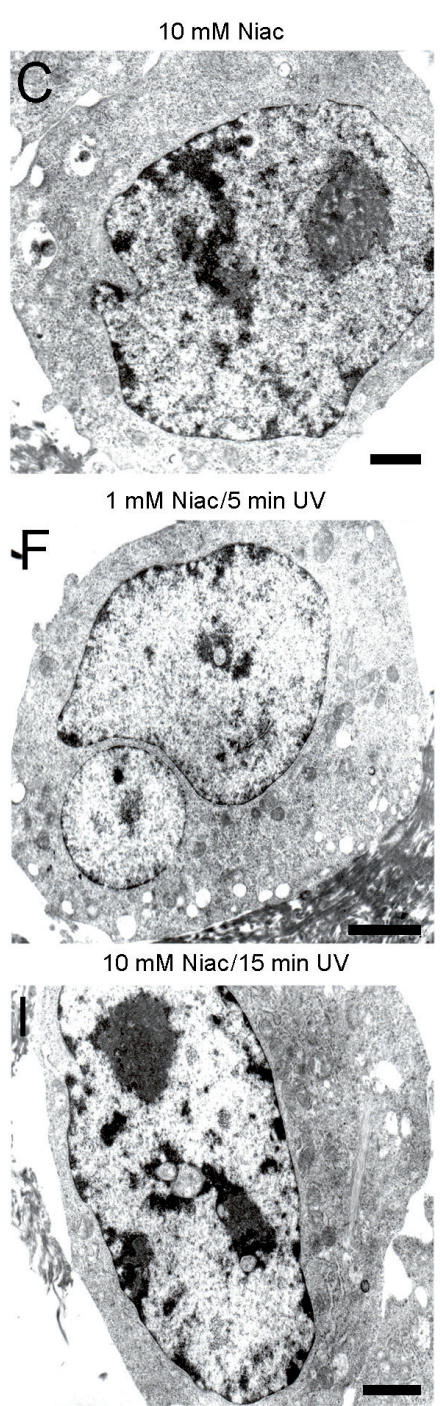

Fig. 6. Transmission electron micrographs of $\mathrm{CHO}$ AA8 cells

A - electron micrographs of control cells; B - cells treated with $1 \mathrm{mM}$ of niacinamide; $\mathrm{C}$ - cells treated with $10 \mathrm{mM}$ of niacinamide; $D$ - cells exposed to $5 \mathrm{~min} U V_{\text {; }}$ E - cells exposed to 15 min UV; the combination of both factors: $\mathrm{F}-1 \mathrm{mM} \mathrm{Niac} / 5 \mathrm{~min}$ UV; G - $1 \mathrm{mM}$ $\mathrm{Niac} / 15 \mathrm{~min}$ UV; $\mathrm{H}-10 \mathrm{mM}$ $\mathrm{Niac} / 5 \mathrm{~min}$ UV; I - $10 \mathrm{mM}$ $\mathrm{Niac} / 15 \mathrm{~min}$ UV; Bar $=5 \mu \mathrm{m}$. 
of UV radiation, including alterations in proteins or DNA, $\mathrm{N}_{2}$ fixation, as well as a reduction in cell growth and division. ${ }^{14}$ Furthermore, Britt showed that UV radiation induces DNA damage and alterations in replication and transcription, leading to deletions of nitrogenous basis. ${ }^{15}$ Moreover, UV radiation results in the induction of oxidative stress, and it is involved in skin carcinogenesis. ${ }^{16}$ The research presented here was performed on one of the experimental models commonly used in many biological, pharmaceutical and medical studies - Chinese hamster ovary cell line (CHO AA8).

According to the literature, vitamins are necessary for proper cell functioning, development, and metabolism in each organism. It is known that the group of 13 vitamins, including vitamin $\mathrm{A}, \mathrm{C}, \mathrm{B}, \mathrm{K}$, and $\mathrm{D}$ has many beneficial features and probably prevent cancers and various diseases, such as cardiac disorders, arthritis and diabetes. This is why a diet rich in vegetables and fruits, and hence rich in many vitamins, is an important factor in maintaining good skin condition. In particular, vitamins A, B, $C$, and E exert an effect on moisture, spots, redness, and wrinkles of the skin. Among them, niacinamide (an amide form of vitamin $\mathrm{B}_{3}$ ) has been described as an agent that can improve skin condition stabilize epidermal barrier function and inhibit photocarcinogenesis. ${ }^{2,8}$

In the present study, we reported that niacinamide specifically induces reorganization of main cytoskeleton proteins such as $\mathrm{F}$-actin, vimentin and $\beta$-tubulin, resulting in the protection against UV irradiation-induced apoptosis in $\mathrm{CHO}$ AA8 cell line. We found that UV radiation results in the decrease of cell survival and the increase in the percentage of apoptotic cells. Similar data was presented by Grzanka et al., where the CHO AA 8 cells were irradiated by UVC for $2 \mathrm{~min}$ at a fluency of $100 \mathrm{~J} / \mathrm{m}$. They also observed morphological changes typical for programmed cell death. ${ }^{17}$ It has also been reported that UV radiation results in cell death in mammalian cell lines, including non-small cell lung cancer (A549), breast cancer (MCF7), human kidney cells (293), HeLa cells, and keratinocytes. ${ }^{11,18-21}$ What is more, the data presented here showed that the treatment of $\mathrm{CHO}$ AA8 cell line with different concentrations of niacinamide did not induce the increase in cell population characterized by hallmarks typical for apoptosis. According to Knip et al., compounds of niacin, such as niacinamide, are non-toxic, while Iwata et al. suggested that the amides of vitamin B may promote differentiations in HL-60., ${ }^{1,22,23}$ We presented here that the combination of niacinamide and exposure to UVB resulted in the decrease of the number of apoptotic cells as compared to UV-irradiated CHO AA8 cells. Surjana et al. suggested that nicotinamide (= niacinamide) possesses protective properties against ultraviolet radiation. In their study on human keratinocytes $\mathrm{HaCaT}$ and ex vivo skin pre-treated with nicotinamide and exposed to ssUV (UVA + UVB), they demonstrated that these forms of niacin enhanced the repair of UV-induced DNA damage through the reduction of CPDs and 8oxoG. ${ }^{3,24}$ Furthermore, other studies showed that nicotinamide prevented immune suppression (human and mice) and cellular energy loss (human keratinocytes) induced by ultraviolet irradiation, and also by carcinognesis (mice). ${ }^{3,25}$

Here, we confirmed that ultraviolet irradiation induces apoptosis, which was manifested by the higher percentage of sub-G1 cells population and the lower percentage of cells with DNA content corresponding to $S$ phase. Several other studies also revealed that UV results in G2 arrest of cell cycle in human keratinocytes, human skin fibroblasts W1 and in SV40 cells. ${ }^{26,27}$ Surjana et al. reported that amides of niacin did not affect cell division. ${ }^{3}$ The data presented here also shows that nicotinamide did not cause significant changes in $\mathrm{CHO}$ AA8 cell cycle distributions.

Despite numerous hypotheses, the protective mechanisms of niacinamide action against UV radiation are still not well understood. The knowledge of the cytoskeleton has been expanding for several decades, and it is known that this structure plays a critical role in almost all cellular processes. In our study, we observed that UV radiation led to the reorganization and degradation of F-actin, $\beta$-tubulin and vimentin. Similar changes in the microfilament network were described by Veselká and Janisch, Grzanka et al. and Klimaszewska-Wiśniewska et al. They also noticed that UV-irradiated cells were characterized by the presence of F-actin aggregates and high-intensity fluorescence of actin fibers, especially in the perinuclear regions in shrunk cells. ${ }^{11,17,28}$ Desozua et al. suggested that the alterations in actin cytoskeleton may be a reference to the assessment of apoptosis. ${ }^{29}$ Furthermore, the disturbances of microfilament reorganization may result in incorrect cells adherence, and then lead to apoptosis, which in our experiments was confirmed by the presence of rounded cells population and a higher percentage of apoptotic cell after irradiation by UV. ${ }^{30}$ Veselká and Janisch presented the effect of UV radiation on the microtubule network in fibroblast L929 cell lines and showed its reduction, thickening and fragmentation. ${ }^{28,30}$ Our results also showed restricted distribution of $\beta$-tubulin in UV-irradiated cells. Moreover, Grzanka et al. demonstrated that UV exposure results in disassembly in microtubules and condensation of intermediate filaments in the perinculear area in other cell lines. ${ }^{17}$ Here, after UV irradiation, CHO AA8 cells also possessed the depolymerized vimentin, most strongly located in the nuclear region. Our studies confirmed the negative effect of UV on morphology and cytoskeletal proteins, and we suggest that these changes lead to cell death. Based on our knowledge, there are no similar papers on the effect of niacinamide as a factor applied alone and in combination with UV on Chinese hamster ovary cell line, especially in the context of cytoskeleton network. In the present study, we showed that niacinamide-treated cells did not show significant differences in cytoskeletal structures as compared to untreated cells. Moreover, we noticed that after pre-treatment with niacinamide and 
then exposure to UV, the CHO AA8 cells seemed to be more flattened and thus more attached to the surface in comparison to UV-irradiated cells. This was confirmed by the fact that we observed intensive fluorescence of microfilaments in the cortical area in cells, which suggests enhanced adherent properties of the cells. Furthermore, we noticed a higher number of stress fibers and enlarged cells characterized by an extensive, bold network of cytoskeletal proteins. In addition, the presence of strongly labeled vimentin in ring-like form localized in the perinuclear region may augment filament assembly to build new intermediate filaments, and hence strengthen the network. ${ }^{31}$ Moreover, we showed that pre-treatment with niacinamide and then exposure to UV promotes cell growth and division in the form of visible mitotic figures and similar percentages of cells in S phase. In summary, we suggest that the amide of vitamin $B_{3}$ induces the stabilization of microfilaments and intermediate filaments.

Our transmission electron microscope results presented cells which were characterized by visible condensation of chromatin, nucleus segmentation, vacuolization of cytoplasm, or swollen mitochondria after ultraviolet irradiation. Likewise, Grzanka et al. showed that Chinese hamster ovary cells after exposure to UV irradiation exhibited similar alterations. ${ }^{17}$ Furthermore, other authors described the appearance of alterations in different UV-treated types of cell lines such as non-small lung cancer A549 and melanoma WM35 cells lines. ${ }^{11,32}$ On the other hand, niacinamide-treated cells predominantly showed essentially normal ultrastructure; in addition, swollen mitochondria were sporadically presented. Similar results were reported by Petrali et al., who described the protective effect of niacinamide on human lymphocytes and showed that the chosen amide of vitamin $\mathrm{B}_{3}$ did not cause significant changes at the ultrastructural level as compared to the control. ${ }^{33}$ The results presented here showed that the treatment with a combination of both factors (niacinamide and UV) induced visible changes in the nucleus area and less destruction of the cytoplasm as compared to ultraviolet irradiated $\mathrm{CHO}$ AA8 cells. In this paper, we described for the first time the influence of niacinamide and its combination with UV on the ultrastructural changes in the $\mathrm{CHO}$ AA8 cells.

It has been shown that vitamin $B_{3}$ protects human keratinocytes against UV irradiation. Lin et al. have shown that co-incubation with niacin enhances the pro-survival pathway (through mTOR, AKT, S6) in HaKaT cells, and thus protects against cell death induced by UV. ${ }^{34}$ Moreover, the effect of niacinamide on the primary melanocytes cell line has been reported by Thomson et al. They suggested that this form of vitamin B enhances the repair of DNA damage. ${ }^{24}$ Several other studies described the protective properities of niacinamide. ${ }^{3,7,33,35,36}$ Nevertheless, the data presented here allows us to assume that niacinamide protects $\mathrm{CHO}$ AA8 cells against ultraviolet exposure.
In conclusion, we described for the first time the influence of niacinamide on cytoskeletal proteins such as Factin, vimentin and $\beta$-tubulin, also at the ultrastructural level in Chinese hamster ovary cell line. Moreover, our results also confirmed the harmful effects of UV radiation on chosen experimental material. Data presented in this paper may provide new information on niacinamide in the context of protection properties. Furthermore, we suggested that this compound can protect cells against ultraviolet irradiation, and the mechanism of action may be related to the stabilization of cell cytoskeleton. These results are very important for the development of primary biological sciences, because the full mechanism of niacinamide is still unexplained.

\section{References}

1. Sauve $A A$. $\mathrm{NAD}^{+}$and vitamin $\mathrm{B}_{3}$ : From metabolism to therapies. J Pharmacol Exp Ther. 2008;324:883-893.

2. Kirkland JB. Niacin status and treatment-related leukemogenesis. Mol Cancer Ther. 2009;8:725-732.

3. Surjana D, Halliday GM, Damian DL. Nicotinamide enhances repair of ultraviolet radiation-induced DNA damage in human keratinocytes and ex vivo skin. Carcinogenesis. 2013;34:1144-1149.

4. Carlson LA. Niaspan, the prolonged release preparation of nicotinic acid (niacin), the broad-spectrum lipid drug. Int J Clin Pract. 2004; 58:706-713.

5. Gale EA, Bingley PJ, Emmett CL, Collier T; European Nicotinamide Diabetes Intervention Trial (ENDIT). A randomised controlled trial of intervention before the onset of type 1 diabetes. Lancet. 2004;363: 925-931.

6. Feng Y, Paul IA, LeBlanc MH. Nicotinamide reduces hypoxic ischemic brain injury in the newborn rat. Brain Res Bull. 2006;69:117-122.

7. Lorencini M, Brohem CA, Dieamant GC, Zanchin NI, Maibach HI. Active ingredients against human epidermal aging. Ageing Res Rev. 2014;15:100-115.

8. Gehring W. Nicotinic acid/niacinamide and the skin. J Cosmet Dermatol. 2004;3:88-93.

9. Narayanan DL, Saladi RN, Fox JL. Ultraviolet radiation and skin cancer. Int J Dermatol. 2010;49:978-986.

10. Surjana D, Halliday GM, Damian DL. Role of nicotinamide in DNA damage, mutagenesis, and DNA repair. J Nucleic Acids. 2010. doi: $10.4061 / 2010 / 157591$

11. Klimaszewska-Wiśniewska A, Redzimska M, Izdebska M, Grzanka A. Ultraviolet radiation (UV) induces f-action rearrangement and cell death in the A549 human lung cancer cell line. Med Biol Sci. 2014;28: 17-21.

12. Klimaszewska-Wiśniewska A, Hałas-Wiśniewska M, Nadrowski T, Gagat M, Grzanka D, Grzanka A. Paclitaxel and the dietary flavonoid fisetin: A synergistic combination that induces mitotic catastrophe and autophagic cell death in A549 non-small cell lung cancer cells. Cancer Cell Int. 2016;16:10.

13. Sinha RP, Häder DP. UV-induced DNA damage and repair: A review. Photochem Photobiol Sci. 2002;1:225-236.

14. Rastogi RP, Richa, Kumar A, Tyagi MB, Sinha RP. Molecular mechanisms of ultraviolet radiation-induced DNA damage and repair. J Nucleic Acids. 2010;592980. doi:10.4061/2010/592980

15. Britt AB. Repair of DNA damage induced by solar UV. Plant Physiol. 1995;108(3):891-896.

16. Armstrong BK, Kricker A. The epidemiology of UV induced skin cancer. J Photochem Photobiol B. 2001;63:8-18.

17. Grzanka D, Domaniewski J, Grzanka A, Zuryn A. Ultraviolet radiation (UV) induces reorganization of actin cytoskeleton in CHOAA8 cells. Neoplasma. 2006;53:328-332.

18. Ferguson HA, Marietta PM, Van Den Berg CL. UV-induced apoptosis is mediated independent of caspase-9 in MCF-7 cells: A model for cytochrome c resistance. J Biol Chem. 2003;278:45793-45800. 
19. Wu S, Loke HN, Rehemtulla A. Ultraviolet radiation-induced apoptosis is mediated by Daxx. Neoplasia. 2002;4:486-492.

20. Kulms D, Pöppelmann B, Shwarz T. Ultraviolet radiation-induced interleukin- 6 release in HeLa cells is mediated via membrane events in a DNA damage-independent way. J Biol Chem. 2000;275:1506015066.

21. Katiyar SK, Mantena SK, Meeran SM. Silymarin protects epidermal keratinocytes from ultraviolet radiation-induced apoptosis and DNA damage by nucleotide excision repair mechanism. PLoS One. 2011;6: e21410.

22. Knip M, Douek IF, Moore WP, et al. Safety of high-dose nicotinamide: A review. Diabetologia. 2000;43:1337-1345.

23. Iwata K, Ogata S, Okumura K, Taguchi H. Expression of CD38 in human promyelocytic leukemia HL-60 cell line during differentiation by niacin-related compounds. Biosci Biotechnol Biochem. 2003;67:18361839.

24. Thompson BC, Surjana D, Halliday GM, Damian DL. Nicotinamide enhances repair of ultraviolet radiation-induced DNA damage in primary melanocytes. Exp Dermatol. 2014;23:509-511.

25. Park J, Halliday GM, Surjana D, Damian DL. Nicotinamide prevents ultraviolet radiation-induced cellular energy loss. Photochem Photobiol. 2010;86:942-948.

26. Gentile M, Latonen L, Laiho M. Cell cycle arrest and apoptosis provoked by UV radiation-induced DNA damage are transcriptionally highly divergent responses. Nucleic Acids Res. 2003;31:4779-4790.

27. Lo HL, Nakajima S, Ma L, et al. Differential biologic effects of CPD and 6-4PP UV-induced DNA damage on the induction of apoptosis and cell-cycle arrest. BMC Cancer. 2005;5:135.
28. Veselká R, Janisch R. The effect of UV irradiation on changes in cytoskeleton and viability of mouse fibroblasts L929 cell line. Scripta Medica. 2000;73:393-408.

29. Desozua M, Gunning PW, Stehn JR. The actin cytoskeleton as a sensor and mediator of apoptosis. Bioarchitecture. 2012;2:75-87.

30. Weinreb O, Dovrat A, Dunia I, Benedetti EL, Bloemendal H. UV-Arelated alterations of young and adult lens water-insoluble alphacrystallin, plasma membranous and cytoskeletal proteins. Eur J Biochem. 2001;268:536-543.

31. Al-Maghrebi M, Brulé H, Padkina M, Allen C, Holmes WM, Zehner ZE. The $3^{\prime}$ untranslated region of human vimentin mRNA interacts with protein complexes containing eEF-1gamma and HAX-1. Nucleic Acids Res. 2002;30:5017-5028.

32. Hussein MR, Haemel AK, Sudilovsky O, Wood GS. Genomic instability in radial growth phase melanoma cell lines after ultraviolet irradiation. J Clin Pathol. 2005;58:389-396.

33. Petrali JP, Oglesby SB, Meier HL. Ultrastructural correlates of the protection afforded by niacinamide against sulfur mustard-induced cytotoxicity of human lymphocytes in vitro. Ultrastruct Pathol. 1990; 14:253-262.

34. Lin F, Xu W, Guan C, et al. Niacin protects against UVB radiationinduced apoptosis in cultured human skin keratinocytes. Int J Mol Med. 2012;29:593-600.

35. LeClaire RD, Kell W, Bavari S, Smith TJ, Hunt RE. Protective effects of niacinamide in staphylococcal enterotoxin-B-induced toxicity. Toxicology. 1996;22:69-81.

36. Benavente CA, Schnell SA, Jacobson EL. Effects of niacin restriction on sirtuin and PARP responses to photodamage in human skin. PLOS One. 2012;7:e42276. 